\title{
POŠta
}

TELEKOMUNIKÁCIE A

ELEKTRONICKY OBCHOD

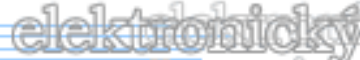

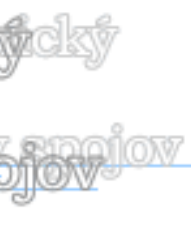

\section{HODNOTENIE POSTAVENIA POŠTOVÝCH PODNIKOV NA TRHU POŠTOVÝCH SLUŽIEB}

\author{
Lucia Madleňáková*
}

\section{Úvod}

Zachovanie univerzálnej poštovej služby ako služby zaradenej do kategórie služieb všeobecného ekonomického záujmu si v zmysle rešpektovania európskej legislatívy vyžaduje dodržiavanie špecifických pravidiel vedúcich na jednej strane k zabezpečeniu stanovenej dostupnosti, kvality a primeranej ceny a na strane druhej k vytváraniu efektívnej hospodárskej sút'aže na trhu s poštovými službami.

Výrazné zmeny na trhoch poštových služieb v krajinách EÚ boli vyvolané postupnou liberalizáciou, dereguláciou a globalizáciou a v neposlednom rade aj uplatňovaním moderných informačných a komunikačných technológií, ktoré stále viac prinášajú do prostredia poštových služieb substitučné efekty a zasiahli aj do rámca univerzálnej poštovej služby. Tento smer vývoja je spojený s rýchlym rozvojom procesov výmeny tovarov a informácií ako aj s orientáciou na integráciu služieb a prudký rozvoj elektronického obchodu. Stanovenie štandardných regulačných pravidiel a ich jednoznačné uplatňovanie v praxi sú nevyhnutným predpokladom pre zabezpečenie fungujúcej konkurencie na trhu poštových služieb, ale tiež príležitost’ou pre poskytovatel'a univerzálnej služby v smere eliminácie negatívnych dopadov uplynulého liberalizačného procesu.

\section{Teoretické aspekty riešenej problematiky}

Základným východiskom legislatívnej úpravy poskytovania univerzálnej poštovej služby v podmienkach slovenského poštového trhu je smernica 97/67/ES, ktorá ukladá členským štátom Európskej únie povinnost' zabezpečit' používatel'om poštových služieb právo na univerzálne služby. Jednotlivé články tejto smernice určujú aj podmienky, podl'a ktorých sa má toto právo zabezpečit' vrátane stanovenia minimálneho rozsahu jej poskytovania. Platný právny rámec SR upravujúci poskytovanie poštových služieb vrátane podmienok pre poskytovanie univerzálnej služby je vymedzený Zákonom č. 324/2011 Z. z. o poštových službách a o zmene a doplnení niektorých zákonov.

Poskytovanie univerzálnej služby (ponuka poštových služieb, ktorá slúži na zabezpečenie minimálneho uspokojenia potrieb všetkých uživatel’ov poštových služieb na území Slovenskej republiky tak, aby bola zabezpečená dostupnost' prístupových miest verejnej poštovej siete a kontaktných miest verejnej poštovej siete, za rovnakých podmienok, $v$ ustanovenej kvalite, za primeranú cenu, každý pracovný den̆ najmenej s jedným vybraním a dodaním denne) môže pre jej poskytovatel'a znamenat' neprimerané finančné bremeno vyplývajúce z podmienok jej poskytovania. V minulosti bolo toto kompenzované existenciou

\footnotetext{
* Ing. Lucia Madleňáková, PhD., Katedra spojov, FPEDAS, Žilinská univerzita v Žiline, tel.: +421415133125, email: Lucia.Madlenakova@fpedas.uniza.sk
} 
tzv. poštovej výhrady, kedy poskytovatel' univerzálnej služby mal výhradné právo na poskytovanie vymedzeného okruhu poštových služieb. Zosúlad'ovaním legislatívneho a regulačného rámca $\mathrm{v}$ dôsledku postupnej kontrolovanej liberalizácie poštového trhu bola regulácia a podmienky poskytovania univerzálnej poštovej služby upravená smernicou 2002/39/ES., so stanovením postupných krokov vedúcich $\mathrm{k}$ zrušeniu poštovej výhrady a úplnému otvoreniu poštového trhu. Tieto snahy boli neskôr zavŕšené schválením smernice 2008/6/ES, ktorá stanovila úplné otvorenie poštového trhu k termínu 1.1.2011 pre pôvodné členské krajiny a k 1.1.2013 pre novo pristúpené členské krajiny EÚ vrátane Slovenska. Postupné znižovanie cenových a hmotnostných limitov vyhradených služieb, znamenalo pre poskytovatel'ov univerzálnej služby hrozbu zvýšenej finančnej zát’aže a povinnost' štátu hl'adat' iné možnosti na financovanie univerzálnej služby.

V podmienkach SR bol poštový trh plne liberalizovaný k 1.1.2012, teda o rok skôr ako sa pôvodne predpokladalo. V dôsledku riešenia otázok financovania univerzálnej služby bolo Zákonom č. 324/2011 Z. z. o poštových službách a o zmene a doplnení niektorých zákonov ustanovené jej financovanie prostredníctvom osobitného účtu v Štátnej pokladnici, ktorý zriadil a spravuje Poštový regulačný úrad SR. Ide vlastne o vytvorenie kompenzačného fondu, ktorého príjmy tvoria príspevky od poštových podnikov a výdavky predstavujú náhradu čistých nákladov na univerzálnu službu v prípade, že poskytovatel' univerzálnej služby preukázal neprimeranú finančnú zát’až čistých nákladov za poskytovanie univerzálnej služby. Metodiku výpočtu čistých nákladov a neprimeranej zát’aže ako aj spôsob výpočtu príspevkov poštových podnikov do kompenzačného fondu upravuje Vyhláška Poštového regulačného úradu č. 63/2012 o spôsobe výpočtu a náhrade čistých nákladov univerzálnej služby.

V súvislosti s riešením problematiky regulácie poštového trhu bol zavedený nový pojem zamenitel'ná poštová služba. Je to poštová služba, ktorá je z hladiska uživatel'a poštovej služby zamenitel’ná $s$ poštovou službou z rozsahu univerzálnej služby. Pri posudzovaní zamenitel'nosti sa berie do úvahy najmä obsah poštovej služby, jej účel a využitie pre uživatel'a poštovej služby, pridaná hodnota poštovej služby a cena za poskytnutie poštovej služby. Poštová služba môže byt' v odôvodnených prípadoch posúdená ako zamenitel'ná aj vtedy, ak sa nevyznačuje všetkými vlastnost'ami poštovej služby z rozsahu univerzálnej služby, akými sú najmä frekvencia dodania či územný rozsah poskytovania.

Riešenie osobitného prístupu $\mathrm{k}$ zabezpečeniu univerzálnej poštovej služby, popri právnej úprave danej zákonom o poštových službách, je zrejmé aj z vykonávania štátnej regulácie $\mathrm{v}$ poštových službách prostredníctvom regulačných nástrojov (vydávanie všeobecné povolenie, udelenie poštovej licencie, rozhodnutia o regulácií cien), ktoré uplatňuje Poštový regulačný úrad. Všetky jeho vydané rozhodnutia musia byt' transparentné, nediskriminačné, primerané technickým a ekonomickým možnostiam poštových podnikov a založené na objektívnych kritériách.

\section{Analýza súčasného stavu v riešenej problematiky}

Výkon regulácie na poštovom trhu sa vzhl'adom na plne liberalizovaný trh a nevyhnutnost' vymedzit' relevantné trhy či riešit' spory týkajúce sa určenia zamenitel'nosti poštových služieb v zmysle platnej legislatívy realizovaný v súčinnosti dvoch orgánov štátnej správy a to Poštovým regulačným úradom, ktorého kompetencie sú vymedzené zákonom o poštových službách a Protimonopolným úradom SR.

Úlohou Poštového regulačného úradu je zabezpečenie regulácie ex ante, to znamená dopredu jasne definovat' pravidlá pre budúci očakávaný vývoj trhu. Ide o presné vymedzene podmienok pre udel'ovanie povolení, ako je poštová licencia a všeobecné povolenie, ale tiež určenie pravidiel registrácie poskytovatel'ov poštových služieb, najmä vo väzbe na zamenitel'né služby. [1] 
Úlohou Protimonopolného úradu SR (upravuje Zákon č. 136/2001 Z. z. o ochrane hospodárskej sút’aže) je riešenie vzniknutej situácie na predmetnom relevantnom trhu. Ide teda prioritne o výkon regulácie ex post. Regulačné opatrenia sa v tomto prípade uplatňujú najmä ak je potrebná arbitráž (t.j. posúdenie argumentov a nedorozumení nezainteresovanou tret'ou stranou), alebo kde nemôžu byt' podmienky definované vopred. Typickým príkladom tohto typu regulácie poštového trhu je regulácia hospodárskej sút’aže, kde regulátor musí rozhodnút' až po udalosti, či boli alebo neboli porušené pravidlá seriózneho sút'aženia na trhu.

Monitorovanie situácie poštového trhu odráža existenciu a pôsobenie rôznych subjektov na poštovom trhu. Regulačný rámec vytvára pravidlá pre registráciu poštových podnikov poskytujúcich poštové služby iné ako univerzálnu službu alebo poštový platobný styk, do registra poštových podnikov. K 24.10.2012 obsahoval register poštových podnikov 21 spoločností, pričom len 7 z nich uvádzalo, že je poskytovatel'om zamenitel'nej služby.

Tabul'ka 1 Zoznam registrovaných poskytovatel'ov poštových služieb

\begin{tabular}{|c|c|c|c|c|c|c|}
\hline & \multirow{2}{*}{ Obchodné meno } & \multicolumn{5}{|c|}{ Druh poštových služieb } \\
\hline & & US & $\overline{\mathbf{Z S}}$ & $\mathbf{U Z}$ & PS & $\overline{\mathbf{O S}}$ \\
\hline 1. & Kolos s.r.o. & & & & & $\mathrm{X}$ \\
\hline 2. & TNT Express Worldwide spol. s r.o. & & & & & $\mathrm{X}$ \\
\hline 3. & ReMax Courier Service, spol. s r.o. & & & & & $\mathrm{X}$ \\
\hline 4. & INSPEKTA SLOVAKIA, a.s. & & & & & $\mathrm{X}$ \\
\hline 5. & GO4 s.r.o. & & & & & $\mathrm{X}$ \\
\hline 6. & Cromwell a.s. & & $\mathrm{X}$ & & & $\mathrm{X}$ \\
\hline 7. & Tatra Billing, s.r.o. & & $\mathrm{X}$ & & & $\mathrm{X}$ \\
\hline 8. & Direct Parcel Distribution SK s.r.o & & & & & $\mathrm{X}$ \\
\hline 9. & Slovak Parcel service s.r.o. & & & & & $\mathrm{X}$ \\
\hline 10. & DHL Express (Slovakia), spol. s r.o. & & & & & $\mathrm{X}$ \\
\hline 11. & IN TIME, s.r.o. & & & & & $\mathrm{X}$ \\
\hline 12. & I.D. Marketing Slovensko s.r.o. & & $\mathrm{X}$ & & & $\mathrm{X}$ \\
\hline 13. & GEIS Parcel SK s.r.o. & & & & & $\mathrm{X}$ \\
\hline 14. & DER KURIER Slovakia spol. s r.o. & & & & & $\mathrm{X}$ \\
\hline 15. & GLS General Logistics Systems Slovakia s.r.o. & & & & & $\mathrm{X}$ \\
\hline 16. & Mediaprint-Kapa Pressegrosso, a.s. & & $\mathrm{X}$ & & & $\mathrm{X}$ \\
\hline 17. & Železničná spoločnost' Slovensko, a.s. & & $\mathrm{X}$ & & & $\mathrm{X}$ \\
\hline 18. & Slovenská pošta, a.s. & $\mathrm{X}$ & & $\mathrm{X}$ & $\mathrm{X}$ & $\mathrm{X}$ \\
\hline 19. & FIEGE s.r.o. & & $\mathrm{X}$ & & & $\mathrm{X}$ \\
\hline 20. & ALFA POST, s.r.o. & & $\mathrm{X}$ & & & $\mathrm{X}$ \\
\hline 21. & SKYNET WORLDWIDE EXPRESS, s.r.o. & & & & & $\mathrm{X}$ \\
\hline
\end{tabular}

Vysvetlivky: US - univerzálna služba ZS - zamenitel'né služby UZ - úradné zásielky OS -

ostatné poštové služby PS - poštový platobný styk

Zdroj: Vlastné spracovanie podla http://www.posturad.sk/article.php?id=24 [cit: 2012-10-24]

\section{Ciel' a metodika}

Ciel'om príspevku je priblížit' problematiku regulácie a hodnotenia postavenia poštových podnikov na trhu poštových služieb. V príspevku je vymedzený návrh hodnotiacich kritérií, odzrkadl'ujúci činnost' poštového podniku poskytujúceho univerzálnu službu, ide však o univerzálne hodnotiace kritéria umožňujúce mapovanie akéhokol'vek poštového podniku. Neodmyslitel'nou súčast'ou analýz na poštovom trhu je uplatňovanie matematicko-analytických metód umožňujúcich posudzovanie koncentrácií či miery diverzifikácie. 


\section{Výsledky a diskusia}

V dôsledku plne liberalizovaného poštového trhu je nevyhnutné, aby poskytovatel' univerzálnej služby monitoroval svoje postavenie na trhu. Mieru liberalizácie môže poskytovatel' posudzovat' prostredníctvom rôznych ukazovatel'ov ako je napr. flexibilita poštového operátora, úroveň dosahovanej efektívnosti pri napĺn̆aní súčasných trendov, využívanie nových technológií, pracovné podmienky v sektore.

Vo všeobecnosti je možné konštatovat', že operátor poskytujúci vysoko efektívne služby získa konkurenčnú výhodu na otvorenom trhu, pretože optimálna nákladová štruktúra a procesy sa premietnu do nižších jednotkových nákladov, ktoré budú st'ažovat' vstup nových operátorov. Zahíňajú sa tu: [3]

- miera franšízingových pôšt,

- vývoj nových produktov poskytovatel’a univerzálnej poštovej služby,

- opatrenia zamerané na zvýšenie produktivity práce,

- celkové náklady vyplývajúce z povinnosti poskytovat' univerzálnu službu,

- schopnost' manažmentu reštrukturalizovat' sa,

- sadzby za poskytované služby.

\subsection{Kritéria hodnotenia trhu s poštovými službami}

\subsubsection{Kvalitatívne ukazovatele}

Trh poštových služieb je možné hodnotit' na základe rôznych kritérií. Dostupné informačné zdroje neuvádzajú jednoznačné hodnotiace kritéria pre všetky poštové podniky na trhu, ani pre potreby vyhodnocovania situácie na jednotlivých relevantných trhoch. Krajiny EÚ však vyhodnocujú predovšetkým kvalitatívne ukazovatele univerzálnej poštovej služby, ktoré zohl'adňujú:

- geografické pokrytie krajiny s určitými výnimkami, frekvenciu poskytovania služieb vyberania a dodávania zásielok,

- kvalitu služieb podl'a časového kritéria alebo s orientáciou na iné kritéria univerzálnej služby,

- dostupnost' siete, ktorá zahŕňa hustotu poštových prevádzok a poštových schránok.

Pri zohl'adnení ukazovatel'ov pre hodnotenie kvality univerzálnej služby a zovšeobecnení požiadavky hodnotit' celý trh poštových služieb, je možné stanovit' nasledovné hodnotiace kritéria: [10]

- rastový potenciál kvality a kvalita poskytovanej služby z pohl’adu zákazníka,

- cenový boj o zákazníka v spojitosti s cenovou hladinou a vývojom cien poštových služieb,

- efektivita univerzálnej poštovej služby (produktivita a funkčná efektivita),

- zákaznícka vol'ba.

\section{Rastový potenciál kvality služieb}

Rastový potenciál kvality služieb je možné posudzovat' podl'a štyroch základných parametrov:

- percento podielu zásielok prvej triedy $(\mathrm{D}+1)$,

- frekvencia vyberania a dodávania listových zásielok, ktorá je postavená na princípe priamej úmery kvality služby $\mathrm{v}$ závislosti od kratšej doby dodania, respektíve vyberania listových zásielok,

- počet aktívnych poštových prevádzok na 10000 obyvatel'ov krajiny. Čím je nižší počet poštových prevádzok na 10000 obyvatel'ov, tým sa zvyšuje pravdepodobnost' potenciálnych konkurentov $\mathrm{v}$ trhovej oblasti. Poskytovatelia univerzálnej služby 
v zmysle požiadaviek stanovených pre dostupnost' prístupových a kontaktných miest majú povinnost' zriadit' vyššie percento aktívnych prevádzok ako iní poskytovatelia.

- percento opýtaných respondentov, ktorí hodnotia služby ako dobré alebo sú s poskytovaním služby spokojní.

Cenový boj o zákaznika v spojitosti s cenovou hladinou a vývojom cien poštových služieb

Cenovú konkurencieschopnost' je možné posudzovat' dvoma spôsobmi. Prvým je cena za dodanú korešpondenciu 1. triedy do 50 gramov. Druhou možnost'ou je priemerný ročný cenový vývoj v porovnaní s predchádzajúcimi obdobiami.

\section{Efektivita univerzálnej poštovej služby (produktivita a funkčná efektivita)}

Pokial' ide o efektivitu univerzálnej poštovej služby, je možné rozlíšit' tri faktory napomáhajúce potenciálnemu rastu kvality a efektívnosti univerzálnej služby:

- percentuálne vyjadrenie počtu listových zásielok spracovávaných automatizovane,

- prevádzkový zisk poskytovatel'a univerzálnej poštovej služby ako percento z príjmov. Čím nižší zisk, tým je vyššia možnost' zlepšenia efektivity služby.

- priemerný počet poštových zásielok spracovaných spôsobom FTE (Full Time Equivalent). Čím nižšia je produktivita práce, tým vyššia je možnost' potenciálneho rastu.

\section{Zákaznícka vol'ba}

Spočíva vo výbere smerom od zákazníka $\mathrm{k}$ poštovému operátorovi a súčasne je odzrkadlením orientácie poštových operátorov na určitý segment trhu z hl'adiska objemu využívania poštových služieb.

Ďalšie kategórie kritérií, ktoré je možné pri posudzovaní situácie na trhu využit', najmä pri posudzovaní postavenia poskytovatel'a univerzálnej služby sú kritéria makroekonomické a mikroekonomické.

\subsubsection{Makroekonomické kritéria}

Makroekonomické kritéria ako kritéria vonkajšie, ktoré poskytovatel' univerzálnej poštovej služby väčšinou nemôže ovplyvnit': [4]

- hustota poštovej služby, ktorá je závislá na geografických podmienkach, respektíve charakteristikách určitej krajiny, čo v konečnom dôsledku ovplyvňuje mieru a rozsah poštového trhu,

- dynamika trhu, ktorá znamená pomerný rast trhu s poštovými službami,

- konkurenčný súboj, ktorý spočíva $\mathrm{v}$ pomernej atraktivite trhu s poštovými službami pre nových poskytovatel'ov poštových služieb v danej krajine.

\section{Hustota poštovej sluz̆by} premenné:

Na zhodnotenie hustoty poštovej služby musíme brat' do úvahy tri geograficky závislé

- počet jednotlivých zásielok na jedného obyvatel'a. Tento ukazovatel' vylučuje neadresné poštové zásielky, ktoré predstavujú značný objem v mnohých krajinách a je potrebné jeho zhodnotenie v rámci rastu trhu.

- percento obyvatel'stva žijúce v mestských zónach. Č́ím nižšie je percento obyvatel'stva žijúceho $\mathrm{v}$ mestských oblastiach, tým sa zvýšia relatívne náklady na doručovanie zásielok do vidieckych oblastí. Za predpokladu cenovej rovnorodosti, rozdiel medzi jednotkovou cenou a nákladmi na doručovanie poštových zásielok do mestských zón bude vyšší.

- hustota obyvatel'stva, teda počet obyvatel'ov na jeden kilometer štvorcový.

Pri nízkej hustote obyvatel'stva dochádza $\mathrm{k}$ rovnakému dopadu ako pri predchádzajúcom ukazovateli. Naopak pri vysokej hustote obyvatel'stva a miere urbanizácie dochádza k zníženiu stupňa rizikovosti pre poskytovatel'a univerzálnej poštovej služby, 
pretože jeho prioritou je pôsobenie na celom území pri maximálnej účinnosti, kde ostáva málo miesta pre konkurenciu.

\section{Dynamika trhu}

- tempo rastu objemu zásielok. Č́m je nižšie tempo rastu objemu zásielok, tým vyššie je potenciálne riziko pre poskytovatel'a univerzálnej poštovej služby. Ukazovatel' zahŕňa aj neadresné zásielky.

- počet poštových zásielok na jedného obyvatel'a. Pri nižšom počte zásielok je podnik vystavený väčšej miere rizika, zatial' čo vysoké počty zásielok môžu mat' taktiež v konečnom dôsledku negatívny efekt. Tento efekt je spôsobený nedostatočným priestorom pre trhový rast.

- percento reklamných zásielok z celkového objemu trhu. Vyššie percento reklamných zásielok indikuje zmenšenie priestoru pre trhový rast a predstavuje teda vyššiu mieru rizikovosti. Tento ukazovatel' zahŕňa objemy neadresných zásielok. Bez nich by hodnoty väčšiny európskych krajín kolísali v rozmedzí $8-20 \%$.

\section{Konkurenčný súboj}

- vel'kost' trhu. Č́m je trh väčší, tým viac príležitostí vstupu na trh sa možnej konkurencii naskytuje. Tento ukazovatel' zahŕňa objemy neadresných zásielok, ak sú tieto objemy známe.

- percento zásielok business-to-consumer (B2C) z celkového objemu zásielok. B2C predstavujú atraktívne objemy vo vel'kom meradle. Čím je pomer B2C zásielok vyšší, tým ohrozenejší je poskytovatel' univerzálnej poštovej služby zo strany potenciálnych poštových podnikov vstupujúcich na trh so zameraním sa na objemy B2C. [2]

- koncentrácia trhu expresných a kuriérskych služieb. Vysoko koncentrovaný trh naznačuje dobrý potenciál pre novo vstupujúce podniky na trh.

\subsubsection{Mikroekonomické kritéria}

Mikroekonomické kritéria ako výzvy a príležitosti príznačné pre poskytovatel'a univerzálnej poštovej služby: [4]

- relatívne náklady, teda zhodnotenie miery nákladov na poskytovanie univerzálnej poštovej služby,

- závislost' na ziskovosti z poštových zásielok, vyhodnocovanie zásielok ako zdroj príjmu,

- odhadnutie hodnoty prínosu poskytovatel'a univerzálnej poštovej služby za pomoci použitia vyššie popísaných kritérií kvality služieb a cenovej konkurencieschopnosti.

\section{Relatívne náklady}

Relatívne náklady sú t’ažko odhadnutel'né vzhl'adom na nedostatok dostupných údajov týkajúcich sa vnútornej štruktúry nákladov poskytovatel’a univerzálnej poštovej služby.

Na lepšie odhadnutie týchto nákladov môžu slúžit' nasledovné kritéria:

- percento počtu zamestnancov zamestnaných na plný úväzok u poskytovatel'a univerzálnej poštovej služby z celkového počtu dostupných zamestnancov. Č́́m je vyšší počet zamestnancov, tým sa zvyšujú relatívne náklady na službu v súvislosti $\mathrm{s}$ využitím trhu práce. Jedná sa o pomer medzi nákladmi na zmluvných zamestnancov, ktorí môžu byt' najímaní podnikmi na trhu poštových služieb a zamestnancov, ktorí by mohli pracovat' pre poskytovatel'a univerzálnej poštovej služby,

- podiel poštových priehradiek. Č́́m nižší je podiel priehradiek, tým väčšie fixné náklady poskytovatel' univerzálnej služby predpokladá a taktiež sa zvýši miera rizika.

\section{Závislost' na ziskovosti z poštových zásielok}

Závislost' na ziskovosti z poštových zásielok napomáhajú objasnit' dve premenné $\mathrm{v}$ závislosti od poskytovatel'a univerzálnej poštovej služby na zásielkach smerom k podpore svojej udržatel'nosti: 
- percento z príjmov mimo poštových zásielok. Vyššie percento predstavuje väčšiu diverzifikáciu pre poskytovatel’a univerzálnej poštovej služby a tým zníženie rizika ohrozenia,

- relatívna pozícia na trhu konkurencie. Silná pozícia podniku v oblasti mimo poštových zásielok poukazuje na nižšiu závislost' od príjmov z poštových zásielok.

\subsection{Posudzovanie koncentrácie na poštovom trhu}

Posudzovanie a hodnotenie situácie na trhu poštových služieb je nevyhnutné najmä v období po ukončenej liberalizácií. Vhodným spôsobom pre zist’ovanie štruktúry trhu a posudzovanie fungovania efektívnej hospodárskej sútaže je využitie rôznych analytických metód, prostredníctvom ktorých je možné matematicky vyjadrit' mieru diverzifikácie. Ide napríklad výpočet ukazovatel'ov ako je: miera koncentrácie vyjadrená prostredníctvom Herfindahl-Hirschmanovho indexu, či Larnerov index, ktorých výpočet sa opiera o štatistické informácie, tiež je možné využit’ tzv. entropiu trhu.

\subsubsection{Herfindahl-Hirschmanovho indexu}

Východiskom pre meranie trhovej sily je podiel na trhu, štruktúra spoločností (koncentrovanost') a jej zmena na trhu meraná pomocou Herfindahl-Hirschman Indexu (d'alej HHI). Podiely na trhu sa zvyčajne počítajú na základe obratu na relevantnom trhu, mimoriadne aj na základe počtu predaných jednotiek. Vo všeobecnosti ak podiel na trhu je 50 \% a vyšší môže byt' sám o sebe považovaný za dôkaz dominantnej pozície na trhu. Podiel na trhu medzi $40 \%$ a 50 \% môže vzbudzovat' obavy v závislosti na ostatných faktoroch, ako je sila a počet sút'ažitel'ov, kapacitné obmedzenia a miera, do akej sú výrobky spájajúcich sa podnikov zamenitel'nými produktmi. Tieto limity sú však pomerne zavádzajúce, a preto je potrebné podrobit' ich testom HHI. [6]

Pri aplikácií HHI indexu na výpočet koncentrácie poštových operátorov na území SR, je potrebné vziat' do úvahy všetkých poskytovatel'ov poštových služieb v SR, zistit' ich percentuálny trhový podiel. HHI index bude teda predstavovat' súčet všetkých umocnených percentuálnych podielov aktívnych poštových operátorov na trhu v SR. Nízka hodnota indexu odzrkadl'uje trh s vysokou konkurenciou v odvetví. Pri vyjadrení indexu do 100 bodov možno charakterizovat' trh ako vysoko konkurenčný s absenciou dominantných hráčov v odvetví. Miera hodnoty do 1000 bodov ukazuje na vyrovnaný nekoncentrovaný trh, toto platí aj pre rozmedzie medzi 1000 - 1800 bodmi. Koncentrácia nízkeho počtu hráčov na trhu je posudzovaná od hodnoty 1800 vyššie. Matematické vyjadrenie HHI: [14]

$H=\sum_{i=1}^{N} s_{i}^{2}$

kde $\mathrm{s}_{\mathrm{i}}$ je trhový podiel podniku $i$ na trhu a $\mathrm{N}$ je počet podnikov fungujúcich na skúmanom trhu.

Pri aplikácií HHI pre trh poštových služieb v SR je potrebné pripomenút' niekol'ko aspektov, ktoré sú späté s vývojom na tomto trhu za posledné obdobie. Poštový trh v krajine v posledných rokoch prešiel významnými legislatívnymi úpravami. Úplná liberalizácia poštového trhu umožnila posudzovanie koncentrácie na trhu poštových služieb. V oblasti univerzálnej služby je možné uvedený index využit' ako podkladovú veličinu pre skúmanie závislosti efektívnosti poskytovatel'a univerzálnej služby, môže byt' odhal'ovaný vzt'ah cenového vývoja alebo kvality služieb vzhl’adom na stav a vývoj koncentrácie trhu.

\section{Koncentrácia na trhu listových zásielok a balikových zásielok}

$\mathrm{Na}$ základe dostupných štatistických údajov je možné situáciu na trhu listových a balíkových zásielok popísat' nasledovne: 
Tabul'ka 2 Údaje o poštovom trhu

\begin{tabular}{|c|c|c|c|c|}
\hline \multirow{2}{*}{\multicolumn{2}{|c|}{$\begin{array}{l}\text { Ukazovatel' } \\
\text { Registrované poštové podnikv }\end{array}$}} & 2008 & 2009 & 2010 \\
\hline & & 21 & 23 & 23 \\
\hline \multirow{2}{*}{$\begin{array}{l}\text { Počet pôšt/prevádzok pre } \\
\text { verejnost' }\end{array}$} & SP, a.s. & 1543 & 1548 & 1548 \\
\hline & Ostatní & 111 & 89 & 75 \\
\hline \multicolumn{5}{|c|}{ Tuzemský styk } \\
\hline \multirow{2}{*}{ Počet listových zásielok } & SP, a.s. & 314502051 & 287456708 & 263984261 \\
\hline & Ostatní & 4150580 & 8137126 & 23923580 \\
\hline \multirow{2}{*}{ Balíky } & SP, a.s. & 3632778 & 3387924 & 3084919 \\
\hline & Ostatní & 6828780 & 7804482 & 8797971 \\
\hline \multirow{2}{*}{ Expresné služby } & SP, a.s. & 500170 & 599530 & 1093586 \\
\hline & Ostatní & 9870530 & 12555770 & 13320514 \\
\hline \multicolumn{5}{|c|}{ Medzinárodný styk - podané zásielky } \\
\hline \multirow{2}{*}{ Počet listových zásielok } & SP, a.s. & 22893330 & 29702061 & 28502566 \\
\hline & Ostatní & 148650 & 127940 & 150934 \\
\hline \multirow{2}{*}{ Balíky } & SP, a.s. & 1864261 & 1827128 & 1826096 \\
\hline & Ostatní & 460575 & 551943 & 725903 \\
\hline \multirow{2}{*}{ Expresné služby } & SP, a.s. & 39643 & 41182 & 43965 \\
\hline & Ostatní & 661857 & 1132518 & 1810944 \\
\hline \multicolumn{5}{|c|}{ Medzinárodný styk - dodané zásielky } \\
\hline \multirow{2}{*}{ Počet listových zásielok } & SP, a.s. & 28771919 & 27174659 & 30056904 \\
\hline & Ostatní & 1627341 & 348931 & 495441 \\
\hline \multirow{2}{*}{ Balíky } & SP, a.s. & 384110 & 365743 & 369764 \\
\hline & Ostatní & 2219614 & 2264094 & 2528738 \\
\hline \multirow{2}{*}{ Expresné služby } & SP, a.s. & 47216 & 44217 & 41142 \\
\hline & Ostatní & 2030184 & 1568583 & 3929258 \\
\hline
\end{tabular}

Zdroj: vlastné spracovanie podl'a http://portal.statistics.sk/files/Sekcie/sek_500/doprava-IKT/rocenka-

doprava_2010.pdf a http://www.posturad.sk/images/upload/Udaje/statisticke_udaje_2009-2011.pdf

Výnosy všetkých poštových podnikov v SR v roku 2010 tvorili 473 mil. €, náklady 483 mil. €., pričom z celkových výnosov tvorili výnosy za listové zásielky $37 \%$, balíky $38 \%$, neadresované zásielky $3 \%$, finančné a ostatné nepoštové služby $22 \%$. Z celkového počtu takmer 1793 mil. zásielok prepravených v SR v roku 2010 tvorili neadresované zásielky $80 \%$, listové zásielky $19 \%$ a balíky $1 \%$.

Na základe zverejňovaných štatistických údajov uvedených v tabul'ke 2, však nie je možné vypočítat' hodnotu HHI, nakol'ko nie je možné vyčíslit' trhové podiely jednotlivých poskytovatel'ov poštových služieb. V zmysle zákona o poštových službách však Poštový regulačný úrad potrebnými údajmi disponuje a je pravdepodobné, že po stanovení relevantných trhov bude uvedená veličina pri analýzach využívaná.

\section{Koncentrácia na trhu expresných služieb}

Ďalším segmentom, kde je aplikovatel'nost' HHI na trhu poštových služieb zrejmá, je trh expresných služieb. Logistické spoločnosti a spoločnosti poskytujúce expresné a kuriérske služby pôsobiace na území SR sa zhodujú v názore, že konkurencia ponúkaných služieb v tejto oblasti narastá a súčasne sa zdokonal'uje. Trendom je schopnost' poskytovatel'a, ktorý bude schopný poskytnút' čo najširšiu škálu služieb od expresnej prepravy, cez tradičnú kamiónovú dopravu, skladovanie až po distribúciu. Podl'a dostupných informácí́ sa podiely na trhu expresných a kuriérskych služieb pohybujú nasledovne:

- DHL Expres (Slovakia),s.r.o. $\quad 43,1 \%$

- Slovak Parcel Service, s.r.o. $\quad 35,1 \%$

- TNT Express Worldwide, s.r.o. $\quad 13,8 \%$

- DPD Slovakia, s.r.o. $\quad 7,7 \%$ 
- Ostatní $0,7 \%$

Pre posúdenie koncentrácie na predmetnom trhu v SR je možné použit’ hodnotu HHI, ktorej zjednodušený výpočet bude vyzerat' nasledovne:

$\mathrm{H}=0,431^{2}+0,351^{2}+0,138^{2}+0,077^{2}+0,007^{2}=0,1858+0,1232+0,0190+0,0059+$ $0,000007=0,3339=33,39 \%$

Pre bodové vyjadrenie podl'a, ktorého sme sa určili hladiny koncentrácie trhu v krajine predstavuje hodnota $26 \%$ hodnotu zodpovedajúcu 3339 bodom. Z výpočtu vyplýva, že slovenský trh s expresnými doručovatel'skými službami je koncentrovaný. Na trhu existuje viac poskytovatel'ov expresných služieb, no vplyvom fúzií a zahraničného kapitálu hrajú 4 hráči na slovenskom trhu významnú úlohu a zastávajú vel'ký podiel na domácom trhu. Ostatní poskytovatelia nemajú prakticky oproti štyrom dominantným podnikom šancu na vyrovnaný konkurenčný súboj.

\subsubsection{Index entropie}

Entropia sa pôvodne využívala v termodynamike ako jedna zo stavových veličín, ktorá meria neusporiadanost' systému. Avšak je možné túto kategóriu využit' aj na meranie úrovne konkurenčného prostredia na trhu poštových služieb. Pre účely takéhoto merania je možné navrhnút' dva spôsoby:

- počet sút'ažiacich, respektíve poskytovatel'ov služieb na trhu,

- entropia.

Štandardné zist'ovacie metódy pozostávajú z definovania počtu poskytovatel'ov služieb podnikajúcich na určitom trhu. Všeobecne sa odhaduje, že sút'až nadobúda efektívnost', ak sú na trhu aktívny minimálne traja poskytovatelia určitej služby. Na samotný rozsah konkurenčného boja na trhu možno použit' tri základné modely:

- na trhu neexistuje konkurenčná sút’až, existuje len jeden poštový operátor. V blízkej minulosti ním bol poskytovatel' univerzálnej poštovej služby pre zásielky týkajúce sa poštovej výhrady,

- na trhu existuje možná konkurenčná sút'až, dvaja vel'kí poskytovatelia poštových služieb majú rozdelený trh určitej krajiny a bránia vstupu d’alšieho operátora na trh,

- pravdepodobná konkurenčná sút’až, kedy na trhu fungujú traja a viacerí poštoví operátori, ktorí cenovou politikou a kvalitou služieb usilujú o zákazníka.

Hoci sa predpokladá, že pri počte troch a viacerých operátorov súčasne pôsobiacich na jednom trhu bude uplatnená hospodárska sút’až, tak je tiež nutné zohl'adnit' rozdelenie služieb využívaných zákazníkmi na danom trhu. Ak má jeden operátor podiel na trhu $90 \%$ a zvyšní dvaja si delia $10 \%$ na polovicu, je t’ažké hovorit' o hospodárskej sút'aži. $Z$ tohto dôvodu sa často využívajú na hodnotenie úrovne trhového systému v krajine indexy koncentrácie trhu. Matematické vyjadrenie entropie: [14]

$H=-\sum_{i=1}^{n} x_{i} \log \left(x_{i}\right)$

kde $n$ predstavuje počet poskytovatel'ov poštových služieb vykonávajúcich obchodnú činnost' na území SR, $x_{i}$ odzrkadl'uje trhový podiel každého poskytovatel'a.

Podl'a použitej formuly vychádzame z nasledovných hodnôt:

- ak je hodnota indexu $\mathrm{H}=0$, tak trh určitej krajiny je využívaný jediným poskytovatel'om,

- ak je hodnota indexu $\mathrm{H}=1$, tak $\mathrm{v}$ hypotetickej rovine na trhu pôsobí rovnomerné postavenie 10 poskytovatel'ov služby.

Rozklad vzt'ahu pre výpočet entropie umožní využit' jej vlastnosti aj pre analýzu podnikovej diverzifikácie a jej vplyv na podnikový rast. Ak vezmeme do úvahy, že trhový podiel určitého podniku na trhu $i$, potom hodnota entropie určuje podnikovú diverzifikáciu. 
Entropia rovná nule charakterizuje podnik ako úzko špecializovaný. $\mathrm{Na}$ druhej strane maximálna entropia odzrkadl'uje maximálnu diverzifikáciu trhu. Otázka diverzifikácie činnosti podniku je aktuálna aj pre oblast' poštových služieb, kde ako bolo naznačené trendom súčasnej doby je hl'adanie komplexného riešenia pre zákazníka.

\section{Záver}

Desat' mesiacov po úplnej liberalizácií poštového trhu je predčasné hovorit' o jej pozitívnych či negatívnych dopadoch. Faktorom braným do úvahy pri posudzovaní situácie na plne liberalizovanom trhu poštových služieb je však pravdepodobnost' straty podielu poskytovatel'a univerzálnej poštovej služby v objemoch zásielok a s tým súvisiaca elasticita dopytu. Predpokladá sa, že trh sa začne správat' podl'a princípov elasticity dopytu a teda podl'a požiadaviek kvality a ceny bude zákazník uvažovat' nad poskytovatel'om poštových služieb. Tento fakt je opät' možné využit' pri výpočte HHI indexu koncentrácie trhového podielu v závislosti na cenách poštových služieb. Úplné otvorenie trhu je tak vel'kou výzvou pre poskytovatel'a univerzálnej služby v smere zvýšit' kvalitu služby tak, aby si zachoval svojich zákazníkov.

Ďalším významným prvkom v súčasnej situácií je vymedzenie relevantných trhov, nakol'ko táto skutočnost' je nevyhnutnost’ou pre zabezpečenie regulačných opatrení najmä v segmente zamenitel’ných služieb vo vzt’ahu k univerzálnej službe. V minulosti otázka relevantných trhov na trhu poštových služieb bola riešená len okrajovo, kedy Protimonopolný úrad SR vo svojich rozhodnutiach pri posudzovaní koncentrácií definoval v rámci podnikatel'ských aktivít jednotlivých účastníkov koncentrácie (s ohl'adom na dopytovú a ponukovú substitúciu a ich priestorovú dimenziu) jednotlivé tovarové relevantné trhy a to nasledovne: [12]

1. Relevantný trh medzinárodného expresného doručovania

2. Relevantný trh medzinárodnej expresnej prepravy nákladov

3. Relevantný trh nákladnej prepravy (medzinárodná alebo vnútroštátna)

4. Relevantný trh tuzemského expresného doručovania

5. Relevantný trh logistiky

Ide však o vymedzenie trhov výlučne pre potreby posudzovania koncentrácie v segmente expresných, kuriérskych a logistických služieb, o čom v minulosti výhradne rozhodoval Protimonopolný úrad. V súčasnosti je však potrebné vyriešit' otázku spolupráce Poštového regulačného úradu SR a Protimonopolného úradu SR pri posudzovaní zamenitel'ných služieb v nadväznosti na právne predpisy z oblasti hospodárenej sút'aže vo vzt’ahu k obdobným typom služieb ako je univerzálna služba, ktorá je poskytovaná ako služba vo verejnom záujme.

\section{Literatúra}

[1] ACHIMSKÝ, K a kol.: Riešenie problematiky zamenitel'ných poštových služieb. Záverečná správa k projektu č. 0275/11 [riešitel'ský kolektív: zodpovedný riešitel': Achimský, K., spoluriešitelia: Achimská, V., Chrenková, A., Madleňáková, L., Rostášová, M.]

[2] BUKOVÁ, B., MADLEŇÁK, R., KUBASÁKOVÁ, I.: Elektronické podnikanie v doprave a logistike. 1. vyd. - Bratislava: Iura Edition, 2009. - 315 s. - ISBN 978-808078-274-0

[3] ČOREJOVÁ, T., FÁBEROVÁ, I.: Regulácia, jej kvalitatívne charakteristiky a metódy hodnotenia dopadov. Konferencia POSTPOINT 2009. vyd. Žilinská univerzita v EDIS - vydavatel'stve ŽU. september 2009. s. 53. ISBN 978-80-554-0085-3 
[4] IMRÍŠKOVÁ, E.: Bariéry makroprostredia vstupu poštových operátorov na trh poštových služieb. Konferencia POSTPOINT 2009. vyd. Žilinská univerzita v EDIS vydavatel'stve ŽU. september 2009. s. 108. ISBN 978-80-554-0085-3

[5] MADLEŇÁKOVÁ, L., MAJERČÁKOVÁ, M.: Legislatíva v poštových službách a elektronických komunikáciách [elektronický zdroj] /. - 1. vyd. - Žilina : Žilinská univerzita v Žilina, 2007. - 1 elektronický optický disk (CD-ROM). - ISBN 978-808070-789-7

[6] MADLEŇÁKOVÁ, L.: Hodnotenie postavenia telekomunikačných operátorov. In: Doprava a spoje: internetový časopis. - ISSN 1336-7676. - Č. 1 (2007), 8 s. Spôsob prístupu: http://fpedas.utc.sk/dopravaaspoje/2007/1/madlenakova.pdf.

[7] MADLEŇÁKOVÁ, L.: Analýza postavenia Slovenskej pošty, a.s. na trhu expresných služieb In: POSTPOINT 2007 : medzinárodná konferencia zástupcov poštových správ a univerzít. Katedra spojov - ŽU Žilina : Žilina 12. - 14. september 2007 : zborník prednášok. - Žilina: Žilinská univerzita, 2007. - ISBN978-80-8070-729-3. - S. 169176.

[8] ŠVADLENKA, L. SALAVA, D., MORKUS, J.: Future role of postal services in the face of new market conditions and communication technologies. Pardubice : University of Pardubice ; 2008. ISBN 978-80-7395-144-3

[9] ZUZÁK R., KÖNIGOVÁ M.: Krizové řízení podniku. Praha: Grada Publishing, 2009. s. 169. ISBN 978-80-247-3156-8

[10] Accenture Report, august 2008. International Postal Liberalization - Comparative Study of US and Key Countries. [online]. [s.a.]. [cit. 2010-04-14]. Dostupné na internete: 〈www.usps.com/postallaw/_pdf/AccentureReport.pdf>.

[11] Cenová regulácia. [online]. [s.a.]. [cit. 2012-10-24]. Dostupné na internete: <http://ec.europa.eu/internal_market/post/doc/legislation/staff-workingpaper_en.pdf >.

[12] Rozhodnutie Protimonopolného úradu SR číslo: 2002/FH/3/1/244

[13] Zákonom č. 324/2011 Z. z. o poštových službách a o zmene a doplnení niektorých zákonov

[14] http://www.econometrics.sk/img/Fundamentalna_analyza_akciovych_trhov.pdf

\section{Grantová podpora}

VEGA 1/0421/12 Modelovanie difúzie znalostí v podnikových hodnotových ret’azcoch IV/KS/2012 Optimalizácia poštových technologických procesov vo väzbe na dopravný systém 